\title{
Black Truffle Production, Soils and Mediterranean Woods: Spanish Research Contributions (1962-2006)
}

\author{
L.G. García-Montero ${ }^{*}, 1$, P. Díaz ${ }^{2}$, I. Valverde ${ }^{3}$, M.A. Grande ${ }^{4}$ and J. Velázquez ${ }^{5}$ \\ ${ }^{I}$ Department of Forestry Engineering, E.T.S.I. Montes, Technical University of Madrid (UPM), Ciudad Universitaria \\ 28040 Madrid, Spain \\ ${ }^{2}$ Department of Industrial Chemistry and Polymers, E.U.I.T. Industrial, Technical University of Madrid (UPM), Madrid, \\ Spain \\ ${ }^{3}$ Department of Soil Science, Facultad de Farmacia. University Complutense of Madrid, Madrid, Spain \\ ${ }^{4}$ Department of Applied Physics and Mechanics, E.T.S.I Montes, Technical University of Madrid (UPM), Madrid, Spain \\ ${ }^{5}$ Department of Projects and Rural Planning, E.T.S.I Montes, Technical University of Madrid (UPM), Madrid, Spain
}

\begin{abstract}
The production of mycorrhizal fungi provides higher economic returns than any other forest product in many Mediterranean woods. In these areas, truffles (Tuber spp.) and mushrooms of Boletus and Lactarius genus are the fungi that yield the highest economic benefits. However, there are still evident gaps in the understanding of the truffle's biological cycles, ecology and interactions with host plants and other fungi. In the last 12 years, Spanish research has begun to respond to the requirements of truffle research. Most of Spanish Tuber references deal with the areas of agronomy, forestry, ecology and soil science. In this respect, Spain is one of the main truffle-producing countries in the world and its varied climate, topography and lithology make it a useful geographic area for increasing knowledge on Tuber ecology and truffle production. This work describes the content of Spanish research and its impact on the knowledge of truffles.
\end{abstract}

\section{INTRODUCTION}

Ectomycorrhizae are formed as a result of the association between fungi and roots of many plant species. Lian et al. [1] and Poma et al. [2] explain that ectomycorrhizae enhance uptake and utilization of nutrients by plant roots, strengthen self-defense ability of plants, facilitate development of plants, and improve soil quality. Ectomycorrhizal fungi are important in the forestation and rehabilitation of vegetative ecosystems, the remediation of soil and water loss, and the diversification of biological species. Moreover, Wang and Hall [3] indicate that the most expensive and sought after of the edible mushrooms belong to the mycorrhizal group. The total market for these is measured in billions of US dollars.

In this regard, the production of mycorrhizal fungi provides higher economic returns than any other forest product in many Mediterranean woods. In these areas, truffles (Tuber Micheli ex Wiggers) and mushrooms of Boletus pinophilus Pilát and Dermek, B. edulis Bull.: Fr. and Lactarius deliciosus L.: Fr. are the fungi that yield the highest economic benefits. Among the Tuber species, the black truffle of Périgord (T. melanosporum Vittad.) is especially appreciated for its culinary value due to its intense aroma, its high yield and the prices it commands (more than $1000 € \mathrm{~kg}^{\prime}$ ). T. melanosporum is of great ecological and forest value because it inhabits carbonated soils in impoverished mountain ecosystems within the Mediterranean continental climate [4-9].

*Address correspondence to this author at the Department of Forestry Engineering, E.T.S.I. Montes, Technical University of Madrid (UPM), Ciudad Universitaria 28040 Madrid, Spain; E-mail: luisgonzaga.garcia@upm.es
Over the past 100 years, harvests of many mycorrhizal mushrooms have declined dramatically, which has prompted interest in the development of methods for their cultivation. Hall and Wang [10] indicate that a few of the ectomycorrhizal fungi can now be cultivated using trees specially infected with the appropriate fungus. Those which command very high prices, like truffles, Tuber melanosporum, and matsutake, Tricholoma matsutake (S. Ito et Imai) Sing., warrant the expense of establishing plantations dedicated to their production. In fact, successful production of Tuber melanosporum is observed in different crops of Europe and other regions, but non controlled factors are still inducing strong heterogeneity in the production from year to year [11].

The biology of Tuber melanosporum has been fully studied and described in extensive monographs. However, there are gaps in our knowledge of T. melanosporum biological cycle, such as its adaptive responses to the physical environment, factors inducing fruiting, soil influence in truffle development and interactions with host plants and other fungi, etc. [9, 12-16].

Bencivenga [17] and Chevalier [18] have confirmed that the ecology of Tuber melanosporum has not been thoroughly explained and that its study is of great importance to improve harvesting, cultivation and natural protection. GarcíaMontero et al. [19] indicate that the international research over the last 10 years has been very limited in regard to studies carried out in natural environments and on plantations; only $16 \%$ of the references deal with the areas of agronomy, forestry, ecology and soil science, while $69 \%$ deal with molecular biology and biochemistry. However these authors explain that in the last 12 years, Spanish research has begun 
to respond to the requirements of truffle research. Specifically, $69 \%$ of the Spanish references deal with the areas of agronomy, forestry, ecology and soil science, and 53\% are based on studies done in natural areas and on truffle plantations. In this respect, Spain's varied climate, topography and lithology make it a useful geographic area for increasing knowledge on Tuber ecology and truffle production. In this regard, Spain's great variability gives rise to singular habitats with symbiotic plants whose western Mediterranean distribution has made their study more difficult in other countries.

Until 1993, the natural production and cultivation of $T u$ ber melanosporum in Spain was relatively unknown, and there was little research being done on the subject; however, this activity has taken on greater importance in recent years. Actually, Spanish production of $T$. melanosporum accounts for between $30 \%$ and $50 \%$ of production worldwide [20,21]. Moreover, since 1994 to 2006, Spanish research has produced at least 200 scientific references [19].

In view of the need to expand current knowledge of the ecology of Tuber melanosporum, and with the aim of increasing production of this valuable forest resource, we have carried out a synthesis of the last ecological studies on quantitative production of carpophores, soil properties and ecology in different Mediterranean woods situated in Spain. Moreover, we review the Spanish research contributions dealing with the biology, ecology and cultivation of T. melanosporum and its impact in the international truffle knowledge. This paper is the second part of a previous paper entitled "Historical summary and reference list of Spanish truffle (Tuber spp.) research (1962-2006)", to show the scientific contents of this Spanish reference list.

\section{SOIL FACTORS THAT INFLUENCE TUBER MELA- NOSPORUM PRODUCTION IN CENTRAL SPAIN}

Different studies have examined which soil properties have the greatest impact on Tuber biology; these include comparisons of the soil requirements of different species of truffles [22-28], analyses of soil variability and its relationship with climate $[29,30]$, and studies relating soil parameters to production and development of T. melanosporum [14, 30-42].

These authors indicate that Tuber melanosporum is strictly calcicolous and grows in calcareous soils with a $\mathrm{C} / \mathrm{N}$ relationship of close to 10 , in which the soil texture is balanced and tends to be simple and well constructed. However, Sourzat [39] indicates that the soil parameters that T. melanosporum tolerates are highly variable. Callot et al. [37], Lulli et al. [38], Castrignano et al. [40] and Ricard [42] report that the development of $T$. melanosporum increases in deep, well-drained, aerated soils with a reservoir of available water during dry periods. Total organic carbon content must be low in order not to modify their $\mathrm{pH}$, and they require considerable porosity, originated by biological activity (above all, by worms and ants). However, Callot et al. [37], Ricard [16] and Garcia-Montero et al. [43] highlight the lack of knowledge as to how the physical-chemical properties of fine soil influence truffle development. Moreover, many authors fail also to supply quantitative data on the relationship between soil properties and truffle production.

In this regard, in the last 10 years, we have developed several studies in Central Spain to explain more fully the impact of surface horizon soil properties on the productivity of Tuber melanosporum carpophores, moreover we analyzed the soil interactions with burn development and host truffle plants, particularly rockroses (Cistus L.), and we study the impact of soil on the interactions between truffle species inside the Tuber melanosporum burns, as T. aestivum Vittad., T. rufum Pico ex Fries and T. mesentericum Vittad. These studies were done in the Alto Tajo Nature Reserve (Peralejos de las Truchas, Guadalajara), a location with several areas of natural populations of $T$. melanosporum $[9,41$, 44-47].

These studies describe that statistical analysis showed that the collective influence of the conventional soil features (granulometric texture, $\mathrm{pH}$, calcareous fractions, organic carbon, total nitrogen, exchangeable cations) on truffle production is low, as PCA explains only $27 \%$ of the variance in Tuber melanosporum production. However, a high percentage of active limestone (calcium carbonate extractable with ammonium oxalate) accounts for up $43 \%$ of $T$. melanosporum carpophore production and $51 \%$ of the variance in the size of T. melanosporum burns.

Active carbonate is a finely-divided fraction of calcareous rock. It is smaller than $50 \mu \mathrm{m}$ in size, very chemically active, and constitutes an important reserve of exchangeable $\mathrm{Ca}^{2+}$. Active carbonate maintains high levels of exchangeable $\mathrm{Ca}^{2+}$ in the soil because it counterbalances losses from leaching and other processes. Active carbonate and exchangeable $\mathrm{Ca}^{2+}$ affects Tuber melanosporum in several ways [12, 48-52]. Ricard [16] indicates that it is difficult to judge the impact of active carbonate on truffle culture because several factors must be considered; he also considers the lack of studies on active carbonate in truffle culture to be an oversight.

In this regard, active carbonate is associated with exchangeable $\mathrm{Ca}^{2+}$ content and stoniness abundance, most importantly, active carbonate regulates soil $\mathrm{pH}$ and participates in the organisation and maintenance of the soil structure, also, $\mathrm{Ca}^{2+}$ is indispensable in the growth of the mycelium of Tuber melanosporum, all of which affect the successful productivity of T. melanosporum carpophores. García-Montero et al. [45] indicate that statistical analysis showed that active carbonate accounted for $42 \%$ of the variance in exchangeable $\mathrm{Ca}^{2+}$ concentration, and the exchangeable $\mathrm{Ca}^{2+}$ abundance explained $20 \%$ of the variance in carpophore production. In addition, a significant correlation was found between active carbonate concentration and surface stoniness.

The availability of active carbonate in the soil depends on complex pedologic, climatic and biological factors. The dissolution, transport and accumulation of carbonates in the soil depend on the relationship between water dissolution and gaseous $\mathrm{CO}_{2}$, soluble $\mathrm{H}_{2} \mathrm{CO}_{3}$ and $\mathrm{HCO}_{3}{ }^{-}$, and solid $\mathrm{CaCO}_{3}$ phases. The solubilisation and leaching of carbonates increases with pluviosity, respiration and metabolism of roots and mycelia, and other factors that increase the partial pressure of $\mathrm{CO}_{2}\left(\mathrm{pCO}_{2}\right)$ in the soil. Bicarbonate precipitates in the form of carbonate when it is concentrated in capillary water (evaporated or absorbed by the roots). This also occurs when the $\mathrm{pCO}_{2}$ diminishes due to aeration caused by macro fauna and the disappearance of the biological respiration of the roots at depth, among other factors [50-53]. 
Tuber melanosporum inhabits Mediterranean dry soils, which the fungi dry up by eliminating plants from their burns. The soil water evaporation and the disappearance of roots in the burns therefore favour surface accumulation of secondary carbonate. This also occurs when the $\mathrm{CO}_{2}$ diminishes due to aeration. In this regard, T. melanosporum is closely related to the aeration of the soil [16, 37, 38, 48, 54]. Our results indicate that the development of the T. melanosporum burn encourages the formation of a large amount of active carbonate and exchangeable $\mathrm{Ca}^{2+}$. T. melanosporum fruition and burn size are simultaneously favoured by a high concentration of both factors, which suggests a feedback process. Finally, these authors indicate that this feedback process provides $T$. melanosporum an additional advantage over its competitors, T. aestivum, T. rufum and T. mesentericum, when active carbonate reaches high soil concentration in the T. melanosporum burns. Therefore, active carbonate is a major factor in the fruiting, burn development, and aggressiveness of $T$. melanosporum versus other truffle species.

For this reason, we propose the study of calcareous amendments with fine limestone to maintain the concentration of active limestone in practical truffle culture. However, these conclusions should be interpreted with caution. In fact many other biotic and abiotic factors play an important role in truffle productivity in cultures and natural burns. Ricard [16] also suggests calcareous amendments of fine limestone in practical truffle culture although he recommends that they should be used with care and in moderation. New studies are required into the effects of active limestone on the biology of Tuber melanosporum, T. brumale and other truffles into the role played by soil and biological processes in maintaining elevated concentrations of active limestone in $T$. melanosporum cultures and natural burns.

\section{FOREST ECOLOGY AND SYMBIOTIC PLANTS THAT INFLUENCE TUBER MELANOSPORUM PRO- DUCTION IN CENTRAL SPAIN}

In truffle culture, the terms "burn", "quemado", "brûlé" or "pianello" are used to describe spots where truffles grow and refers to truffles' phytotoxic capacity and their ability to create clearings in the vegetation where their carpophores bear fruit. Tuber melanosporum burns generally present a circular shape around the symbiotic log, and the vegetationfree surface area spreads outwards at a speed of 10 to $15 \mathrm{~cm}$ per year, sometimes reaching areas several dozen metres in diameter [16, 42, 55-57]. The environmental conditions created by the burns of $T$. melanosporum are very favourable for the development, mycorrhization and fruition of this truffle. However, Callot et al. [34], Ricard [16] and Granetti et al. [42] indicated that the biological and physical-chemical conditions related with burn development have yet to be clarified.

Most studies of Tuber melanosporum fail to supply statistical data on carpophore production and other quantitative data associated with its ecology. In view of the need to expand current knowledge of the ecology of T. melanosporum, and with the aim of increasing production of this valuable forest resource, we have carried out a study on the quantitative production of carpophores, the size of $T$. melanosporum burns and their soil properties in different woods situated close together in the Alto Tajo Nature Reserve, in the central region of Spain. This region is a suitable area for the study of T. melanosporum since it is a continental elevated region with particular substrates and plants whose relationships with T. melanosporum are unknown. This study area has a maximum total production of $500 \mathrm{~kg}$ of $T$. melanosporum carpophores.

During 7 years, we studied 208 burns associated with Quercus ilex subsp. ballota, Q. faginea, Corylus avellana and Tilia platyphyllos in the centre of the Iberian Peninsula $[9,47,58]$. The results showed that burn size is a very significant factor as it accounts for $38 \%$ of the variance in carpophore production. However, no significant difference in the size of burns was observed between five types of wood, although significant variability in carpophore production existed between these wood types. Furthermore, statistical analysis shows that a high concentration of active carbonate in the soil accounts for up to $51 \%$ of the variance in T. melanosporum burn size. The ecological conditions of burns cause elevated concentrations of active carbonate and exchangeable $\mathrm{Ca}^{2+}$, and $T$. melanosporum activity and burn size are simultaneously favoured by a high concentration of both factors, which suggests a feedback process. These results may indicate a possible application for the use of calcareous amendments in natural burns and truffle cultivation.

We also determined the considerable truffle-producing ability and mycorrhizing capacity of Quercus faginea. A1though $Q$. faginea is a very little-known species in truffle culture, the results provide support for its implementation. Moreover, in these studies we conclude that at present Pinus sylvestris L., P. nigra Arnold subsp. salzmannii (Dunal) Franco, Tilia platyphyllos Scop. and T. $x$ vulgaris Hayne (= T. $x$ europaea auct., p.p.) are of little interest to Tuber melanosporum culture, as they hinder carpophore production. However, these studies have also confirmed that pines and lime trees mycorrhize easily with $T$. melanosporum, both in the laboratory and in natural environments. On this basis, we propose that pines and lime trees mycorrhize may act as transmitters of $T$. melanosporum, although they do not induce fruiting. As a result, the commercial cultivation of Pinus nigra salzmannii, P. sylvestris, Tilia platyphyllos and T. $x$ vulgaris seedlings mycorrhized with Tuber melanosporum is not recommended in truffle culture at the present time $[47,58]$.

At the moment, there are very few studies on Tuber melanosporum associated with Cistus L. (rockroses) populations. In Central Spain, we confirm that C. laurifolius L. shows carpophore production of Tuber melanosporum [46, 59]. We demonstrate a correlation between T. melanosporum production and the size of 41 burns, with burn size explaining $26 \%$ of the variability in carpophore production. However, statistical analysis of the results indicates that average production of 21 burns with Cistus laurifolius is $73 \%$ lower than the production of 20 burns associated with Quercus/Corylus without Cistus laurifolius in this zone, respectively. C. laurifolius develops small burns, which has an impact on their carpophore production, and their soils have 92 $\%$ less active carbonate than the burns associated with Quercus/Corylus in this zone, respectively. The low levels of active carbonate allow Cistus laurifolius to grow, but impair Tuber melanosporum production. Moreover, it has also been 
statistically verified that many Cistus laurifolius die in Tuber melanosporum burns, whereas in old burns with minimum carpophore production, a new colonization of young Cistus has been observed. We thus provide a mechanism, based on the inability of $C$. laurifolius to grow in highly carbonated soils, which contradicts the well-known fact that $C$. laurifolius might act as a transmitter of Tuber melanosporum mycorrhizae. Consequently, the commercial cultivation of Cistus laurifolius mycorrhized with Tuber melanosporum for production is not recommended in truffle culture. Moreover, we reported negative observations of carpophore production in cultivations of $T$. melanosporum with other Cistus species.

\section{CURRENT LINES AND IMPACT OF SPANISH RE- SEARCH IN INTERNATIONAL TRUFFLE KNOWL- EDGE}

It can be seen from the bibliography how the effects of the European Union's Common Agriculture Policy and reforestation policies in EU have led to a revival of interest in mycorrhizal plants and truffle cultivation since the 1990s. In Spain, this in turn has meant an increase in the number of nurseries which mycorrhize commercial plants. The Spanish Forestry Strategy [60], on which the Spanish Forestry Plan [61] is based, underlines the importance of promoting research and development into the exploitation of Tuber melanosporum, T. aestivum Vittad. and other truffles in Spanish forests. However, these activities have given rise to new technical and economic problems in UE related to the mycorrhization of commercial plants, the appearance of contaminating fungi, the certification of commercial plants, the importation of Asian truffles, management of truffleproducing forests, and the need to optimise cultivation sites and repopulation efforts, among other aspects.

In addition, the yield of naturally-occurring truffles in Spain and other European forests appears to have decreased significantly in the last decade, making it necessary to study this trend in production more closely. Reyna et al. [62] call attention to this problem and García-Montero et al. [63] describe how certain areas in central Spain shown a $35 \%$ decrease in their maximum annual production of Tuber melanosporum between 1960 and 2002. The decrease in production in this region appears to be associated with the depletion of various truffle-producing areas (due to over-harvesting), an increase in vegetation cover owing to changes in the use of the land (decrease in cattle-farming), and the fact that the average yearly rainfall fell by 35\% between 1960 and 2000 . The climatic effect appears to have been worsening in recent years.

Several lines of investigation have been opened in Spain in order to address these problems. The TESEO database [64], which contains a list of the doctoral theses written in Spain, describes six theses associated to the keyword "Tuber melanosporum", since 1994 to 2008. Moreover, a seventh doctoral thesis on truffle aroma is currently in the final stages; the first phase was completed by Díaz [65].

The doctoral thesis by Reyna [66] (directed by J. A. Rodríguez) proposes a set of models for use in forestry and the management of forest stands with Tuber melanosporum production. These models are developed taking into account social, economic and historical aspects, and are designed to integrate truffle ecology, the state of tree stands and an improvement in forest yields by means of forestry techniques.

The doctoral thesis by Domínguez [67] (directed by J. A. Rodríguez) described in the TESEO data base [64] follows the same line of research, and is designed to increase the presence of Tuber melanosporum in forestry. This author studies the procedures for improving the mycorrhization of T. melanosporum and the use of this truffle in the recuperation of deteriorated ecosystems. To this end, studies have been done on how to improve the quality of the forest profile, the ecology of T. melanosporum, and the dynamic of its mycorrhizas. This author conducted tests with Pinus halepensis Mill., P. nigra, Quercus ilex L., Q. faginea Lam., and Q. petraea (Matt) Liebl. mycorrhized with Tuber melanosporum, and studied the effect of different substrates, inoculate and water stress on the efficiency of the mycorrhization and the quality of the plant.

He also analyses the influence of mycorrhizas on the biometry of the plant, nitrogen and phosphorous assimilation, gaseous exchange and water relations. He then locates potential areas for Tuber melanosporum in eastern Spain and uses cultivation plots to study the mycorrhizas and their contribution to the growth and physiology of Quercus ilex and $Q$. faginea. The author concludes that Tuber melanosporum improves biometry, survival, water availability in situations of stress, and nitrogen and phosphorous assimilation in plants; and he asserts that the host plant and the terrain are the two main factors determining the implantation of mycorrhizas, while the controlled presence of contaminating fungi from the nursery does not represent any significant competition for T. melanosporum in the short term. The first results of this thesis have been published in Domínguez et al. [68].

Another line of research concerning the ecology of Tuber melanosporum can be found in the doctoral thesis by GarcíaMontero [41] (directed by J.L. Manjón) conducted in the Alto Tajo Nature Reserve (Guadalajara). This author propose new ecological data, such as the aforementioned importance of burn sizes, active carbonate in soils inhabited by T. melanosporum, the capacity of Quercus faginea and Q. ilex L. subsp. ballota (Desf) Samp. in truffle production and the difficulty some symbiont plants have in producing Tuber melanosporum sporocarps.

Another problem in Spanish truffle culture is the existence of mycorrhizas and fungi which are harmful to truffles in natural areas and in nurseries with mycorrhized plants. An example is the mycorrhiza known as "form 2" and the discomycete Sphaerosporella brunnea (Alb. and Schwein. ex Fr.) Svrcek and Kubicka, which have been studied at the Universities of Alcalá and Navarra and the Technical University of Madrid (UPM), together with other competing fungi. Regarding S. brunnea, García-Montero et al. [69] confirm that no appreciable damage has occurred in nurseries in central Spain which produce plants mycorrhized with Tuber melanosporum, in spite of the fact that it can clearly be seen to be fruiting in the containers of these plants.

A study of new Tuber mycorrhizas can be found in the doctoral thesis by García-Montero [41] and García-Montero et al. [70], that describe that the mycorrhizas of T. pseudoexcavatum Wang, G. Moreno, L. G. Riousset, J. L. Manjón and G. Riousset, sp. nov., $T$. indicum Cooke and Massee and $T$. 
malençonii Don., Riouss. and Chev. [71, 72]. These results agree with the observations of Amicucci et al. [73], Zambonelli et al. [74] and Comandini and Pacioni [75]. At the present time the authors of this article detect an increase in the presence (both legal and fraudulent) of Asian truffles in Spanish markets, and there is also a rumour (unconfirmed) circulating among European truffle farmers that plantations of plants mycorrhized with Asian Tuber spp. have already been introduced (either accidentally or deliberately), which could spread to the natural environment.

Also on the subject of mycorrhizas which are harmful to truffle culture is a doctoral thesis by Etayo [76] (directed by A. M. De Miguel) described in TESEO [64]. This author monitored a Tuber melanosporum plantation in northeast Spain in order to verify the permanence of its mycorrhizas and their interaction with other competing fungi. This author compares the behaviour of Corylus avellana L., Quercus faginea and Q. ilex subsp. ballota, and analyses the effect of mulching the ground with straw and plastic. This author identifies 14 morphotypes of mycorrhizas inside the cultivated area and 21 morphotypes in the area outside. Etayo demonstrates that the factor most influencing the mycorrhiza community is the tree species, while the type of mulch has less effect. This author also concludes that the symbiont plant which most favours the permanence of the mycorrhizas of Tuber melanosporum is Quercus ilex subsp. ballota.

A doctoral thesis by Román [77] (directed by A. M. De Miguel), described in TESEO [64], also deals with the subject of mycorrhizas and truffle culture. This author studied a mycorrhiza community associated with Quercus ilex subsp. ballota in a forest in the north-east of Spain for 3 years, in a potential area for Tuber melanosporum which had suffered a low-intensity forest fire four years earlier. This author describes and classifies 36 morphotypes of ectomycorrhizas and indicates that the mycorrhiza community is dominated by Cenococcum geophilum Fr. and by a specific group of morphotypes.

Román [77] also explains that the fire caused significant changes in the relative abundance of specific morphotypes and a decrease in the quantity of existing mycorrhized apexes, but it did not alter either the diversity or the specific composition of the mycorrhiza community. This author confirms that in the area affected by the fire, the mycorrhiza community is now in the process of recovery, although with a seasonal variation in mycorrhiza diversity which is highest in autumn and lowest in summer, while the quantity of mycorrhized apexes is highest in winter and lowest in autumn. The author asserts that 3 years after the introduction in the burn area of plants mycorrhized with Tuber melanosporum, it has been observed that the mycorrhizas of this truffle persist, although they have to compete with other mycorrhizal fungi. In conclusion, Román proposes T. melanosporum as a suitable mycorrhiza for reforesting areas damaged by fire.

Finally, a doctoral thesis by Martínez de Aragón [78] (directed by C. Colinas), described in TESEO [64], also deals with the subject of edible mushroom production, mycorrhizas ecology and truffle culture. This author studied the relationship among climate, forest management and productivity of edible mushrooms in 23 plots located in pine woods during 5 years. Moreover, this author analysed the fire effects in the mycorrhizal communities and he devoted particu- lar attention to Tuber melanosporum cultivation in the burned areas.

Although there has been intense activity in Spanish truffle research over the last years, its influence on international truffle knowledge has just begun. Since 1994 to 2006, Spanish research has produced 200 references on truffles developed in 13 centres ( 6 doctoral theses, 67 papers in international scientific congresses, 49 papers in Spanish scientific congresses, 7 documents on websites, 63 published articles, and at least 8 papers submitted) [19].

At 2007, as result of the research until 2006, the Spanish bibliography contains at least 15 papers published in international journals listed in the JCR: Moreno et al. [4] and Wang et al. [79] propose 2 new Asian species of Tuber (however, one of these be regarded as a synonym of $T$. indicum); Moreno-Arroyo et al. [80] provide new information on T. oligospermum (Tul. and C. Tul.) Trappe; Díaz et al. [81, 82] have developed a rapid and objective methodology for differentiating truffles by means of the analysis of their aroma; Domínguez et al. [68] and García-Montero et al. [9, 19, 44-$46,58,59,68]$ articles have been described above; and Suz et al. [83] propose a method using molecular biology to detect Tuber mycelium in the ground. A brief description is given below of the contributions and the international impact of these Spanish papers.

Moreno et al. [4] and Wang et al. [79] describe Tuber pseudohimalayense sp. nov. (recently be regarded as a synonym of $T$. indicum) and $T$. pseudoexcavatum sp. nov. These authors note the importation of Asian truffles which have been flooding the European markets. This is an opportunity to study species of Tuber which are practically unknown here, and although it has brought to light some taxonomic novelties, it has also caused serious damage to the quality of commercial truffles.

Tuber oligospermum is a poorly known species that has several synonyms. Moreno-Arroyo et al. [80] report on the taxonomy, habitat and biogeography of T. oligospermum, and they discuss its most important macroscopic and microscopic features. $T$. oligospermum is an edible truffle found only in the Mediterranean region; it is a circumMediterranean species, with an economic and ecological potential in developing regions (e.g. reforestation with mycorrhizal plants).

Several studies have been done in various countries on the subject of truffle aroma, and specifically on the aroma of Tuber melanosporum, T. magnatum Pico, T. aestivum, $T$. borchii Vittad. and other truffles of lower quality, when fresh, frozen and tinned [84-87]. The techniques used for the extraction of the volatile compounds include both static and dynamic headspace analysis, headspace solid-phase microextraction (HS-SPME) [81, 82], and extraction with organic solvents, among other techniques. The volatiles extracted are subsequently analysed by means of gas chromatography (GC) and/or gas chromatography coupled with mass spectrometry (GC-MS). These studies describe the key compounds in the aroma of T. melanosporum and T. magnatum. $T$. magnatum presents a characteristic compound, bis(methylthio) methane [88], while the aroma of T. melanosporum presents various compounds of interest which contribute to their total aroma $[89,90]$. New developments in- 
clude an "electronic nose" with various sensors which has been applied to T. magnatum [91] and a patent portable truffle detector [92], however the "electronic nose" is still in the field of the research.

The bibliography and the various databases show that the studies on truffle aroma so far have used sporocarps from truffles of French and Italian origin. For this reason, Díaz et al. [81, 82] have applied experimental design and optimization techniques (response surface methodology) to develop an objective method for analysing Spanish truffle aroma, and they are studying the influence of several environmental and population factors of the truffles (intra and interspecific) on the aroma of Tuber melanosporum and other central European truffles. Finally, work has begun on the relationship between the volatile compounds of truffles and several flies of the genus Suillia and beetles of the genus Leiodes present in central Spain [93]. Some publications have already analysed the relationship between dimethyl sulfide and Suillia gigantea [94, 95], and between S. univittata (the garlic fly) and the aroma of Tuber magnatum [96], although nothing has yet been published on the compounds involved in these interactions.

Suz et al. [83] have developed a molecular method to detect mycelia of Tuber melanosporum in soil, and tested the mycelial distribution around 2 truffle-bearing Quercus ilex trees in a truffle orchard. Isolation of total DNA from soil was performed, followed by PCR amplification with Tuber melanosporum specific primers and restriction analysis. To address the detection sensitivity level, soil samples were inoculated with known amounts of gleba of T. melanosporum. Mycelium was detected primarily within the area defined by the truffle burn and within the top $35 \mathrm{~cm}$ of the soil in all directions from the trees.

Moreover, other important Spanish references are Bonet et al. [97] and Reyna [98]. Bonet et al. [97] have tested a method for quantifying irrigation needs for truffle plantations in the establishment phase based on water deficits. They proposed the use of calculating water needs as a function of water deficit in order to promote a rational method that can be adjusted to different sites and conditions. Reyna's [98] books are important on the popularization of the truficulture in Spain, and are essential on the development of the truffle knowledge and research in Spain.

Therefore, Spain is one of the main truffle-producing countries in the world, and is of significant interest to international truffle culture due to its wide diversity of habitats for truffle study and cultivation. For these reasons, at least 13 research centers in Spain have been involved in investigation into truffle culture since 1994, and they have produced more that 217 references until 2007. This activity has shown how truffle research in Spain is now at the same level that other countries such as France $[19,20]$. This documentation is intended to encourage scientific collaboration between Spain and other countries involved in truffle harvest and cultivation, such as Australia, New Zealand and USA.

\section{ACKNOWLEDGMENTS}

We thank Margarita, Luis, Pablo and Miriam for their support and collaboration. We would also like to express our gratitude to $\mathrm{M}^{\mathrm{a}}$ Cruz Gómez-Llano and Faustino Correas of the University Library of E.T.S.I. Montes (UPM) for their help with the bibliography research, and to Prudence Brooke-Turner for her linguistic assistance. We are grateful to the Alto Tajo Nature Reserve Institution and Department of Soil Science of the University Complutense of Madrid.

\section{REFERENCES}

[1] Lian B, Dong YR, Hou WG, Tong LH, Yuan S. Ectomycorrhizal Fungi in Jiangsu Province, China. Pedosphere 2007; 17: 30-5.

[2] Poma A, Limongi T, Pacioni G. Current state and perspectives of truffle genetics and sustainable biotechnology. Appl Microbiol Biotechnol 2006; 72: 437-41.

[3] Wang Y, Hall IR. Edible ectomycorrhizal mushrooms: challenges and achievements. Can J Bot 2004; 82: 1063-73.

[4] Moreno G, Manjón JL, Díez J, García-Montero LG, Di Massimo G. Tuber pseudohimalayense sp. nov. An Asiatic species commercialised in Spain, similar to Périgord truffle. Mycotaxon 1997; 63: 217-24.

[5] Oria JA. Silvicultura y ordenación de montes productores de hongos micorrizógenos comestibles. Boletín de la Sociedad Micológica de Madrid 1989; 13: 175-88.

[6] Oria JA. Bases para la selvicultura y evaluación de montes productores de hongos micorrizógenos comestibles. Montes 1991; 26: 4855 .

[7] Montecchi A, Sarasini M. Atlante fotografico di funghi ipogei Vicenza: Associazione Micologica Bresadola; 2000

[8] Riousset L, Riousset G, Chevalier G, Bardet ME. Truffes dEurope et de Chine. Paris: INRA; 2001.

[9] García-Montero LG, Manjón JL, Pascual C, García-Abril A. Ecological patterns of Tuber melanosporum and different Quercus Mediterranean forests: quantitative production of truffles, burn sizes and soil studies. For Ecol Manage 2007; 242: 288-96.

[10] Hall IR, Wang Y. Edible mushrooms as secondary crops in forests. Quarterly Journal of Forestry 2000; 94: 299-304.

[11] Lefevre CK, Hall IR. Status of truffle cultivation: a global perspective. Acta Hortic 2001; 556: 513-20.

[12] Bencivenga M, Granetti B. Indagine preliminare sull contenuto in macro e microelementi del terreno e di carpofori di Tuber melanosporum Vitt. Micologia Italiana 1989; 3: 25-30.

[13] Pacioni G, Marra L, Eds. Convegno internazionale sul tartufo. Università degli studi L'Aquila, L'Aquila; 1993.

[14] Callot G. La truffe, la terre, la vie. Versailles: INRA; 1999.

[15] Courvoisier M, Olivier JM, Chevalier G, Eds. Federation Française des trufficulteurs: 2001: Actes du V Congrès International Science et Culture de la Truffe; Aix-en-Provence, France; 1999.

[16] Ricard JM, Ed. La truffe. Guide technique de trufficulture. Paris: Centre Technique Interprofessionnel des Fruits et Légumes CTIFL; 2003.

[17] Bencivenga M. La tartuficoltura in Italia: problematiche e prospettive. In: Corvoisier M, Olivier JM, Chevalier G, Eds. Actes du V Congrès International Science et Culture de la Truffe; 1999: Aixen-Provence, France: Federation Française des trufficulteurs; 2001; 27-9.

[18] Chevalier G. Du Congrès de Spoleto a celudi d'Aix-en-Provence: les avancees en matiere de recherches sur la truffe et la truffle culture en France. In: Corvoisier D, Olivier JM, Chevalier G, Eds. Actes du V Congrès International Science et Culture de la Truffe; 1999: Aix-en-Provence, France; Federation Française des trufficulteurs; 2001; pp. 11-14.

[19] García-Montero LG, Pascual C, García-Cañete J, Grande MA, Diaz P. Historical summary and reference list of Spanish truffle (Tuber spp.) research (1962-2006) N Z J Crop Hortic Sci 2007; 35: 12938.

[20] Reyna S, De Miguel AM, Palazón C. Truffle cultivation in Spain: state of the art and future prospects. ITEA (Información Técnica Económica Agraria) Producción Vegetal 2004; 100: 187-99.

[21] Reyna S, García-Barreda S. La truficultura y la selvicultura trufera como apoyo a los sistemas de defensa contra incendios. Revista Forestal Española 2005; 37: 11-8.

[22] Delmas J, Brian C, Delpech P, Soyer JP. Application del'analyse en composantes principales à une tentative de caractérisation physicochimique des sols trufficoles français. Mushroom Science 1981; 11: 855-67.

[23] Raglione M, Lorenzoni P, Simone C, Monaco R, Angius A. Osservazioni sulle caratteristiche pedologiche di alcuni siti di tartufo ne- 
ro pregiato Tuber melanosporum in provincia di Rieti. Micologia e Vegetazione Mediterranea 1992; 7: 211-24.

[24] Mamoun M, Olivier JM. Competition between Tuber melanosporum and other ectomycorrhizal fungi, under two irrigation regimes. Comparison of soils artificially infested with $T$. melanosporum and T. brumale. Plant Soil 1993; 149: 219-25.

[25] Mamoun M, Olivier JM. Competition between Tuber melanosporum and other ectomycorrhizal fungi, under two irrigation regimes. Competition with Tuber brumale. Plant Soil 1993; 149: 211-8.

[26] Zanini E, Giovannetti G, Franchini M, Patetta A. Soil-carpophore interface in some Italian truffle pedo-environments. Agricoltura Mediterranea 1995; 125: 205-14.

[27] Bencivenga M, Calandra R, Giovagnotti E, Russi L. Soil and geobotanical characterization of Tuber mesentericum - T. aestivum and T. aestivum var. uncinatum truffle-beds. Annali-della-Facoltadi-Agraria della Universita degli Studi di Perugia 1998; 50: 7-45.

[28] Raglione M, Spadoni M, Cavelli S, Lorenzoni P, Simone C. Les sols des truffières naturelles de Tuber melanosporum Vitt. dans 1'Apennin central Italie. In: Corvoisier M., Olivier J.M. and Chevalier G., Eds. Actes du V Congrès International Science et Culture de la Truffe; 1999: Aix-en-Provence, France: Federation Française des trufficulteurs; 1999; 276-5.

[29] Bencivenga M, Venturi F, Ranfa A. Indagine preliminare sull'andamento stagionale dell'unmidita'e della temperatura del terreno delle cave di Tuber melanosporum e Tuber magnatum. Micologia e Vegetazione Mediterranea 1988; 3: 37-45.

[30] Bencivenga M, Di Massimo G, Donnini D. Analisi delle micorrize in una tartufaia coltivata di Tuber melanosporum Vitt. undici anni dopo 1'impianto. Micologia e Vegetazione Mediterranea 1992; 7 : 159-71.

[31] Delmas J, Chevalier G, Villenave P, Bardet MC. Mechanical properties of soil and Tuber melanosporum mycorrhizae. Colloques del INRA 1982; 13: 329-35.

[32] Letacon F, Delmas J, Gleyze R. Effect of soil-water regime and fertilization on fructification of the black truffle of perigord Tuber melanosporum Vitt. in South East of France. Acta Oecol 1982; 3: 291-306.

[33] Verlhac A, Giraud M, Pallier R. Truffles. Application of organic fertilizer to yielding, irrigated truffle beds. Infos Paris 1989; 56: 226.

[34] Callot G, Jaillard B. Effect of structural character ristics of subsoil on the fruiting of Tuber melanosporum and other mycorrhizal fungi. Agronomie 1996; 16: 405-19.

[35] Bragato G. Modifications to soil texture and soil organic matter induced by black truffle Tuber melanosporum. Monti e Boschi 1997; 48: 23-7.

[36] Bragato G, Lulli L, Castrignano A, Bencivenga M. Regionalization analysis of some soil factors related to Tuber melanosporum production in an experimental truffle bed. In: Corvoisier D, Olivier JM, Chevalier G, Eds.. 1999. Actes du V Congrès International Science et Culture de la Truffe. 1999: Aix-en-Provence, France; Federation Française des trufficulteurs; 2001; 253-6.

[37] Callot G, Daignieres Y, Fernández D, Raymond M, Salducci X.. Incidences du sol sur la production de truffe noire du Périgord Tuber melanosporum. In: Corvoisier D, Olivier JM, Chevalier G, Eds. Actes du V Congrès International Science et Culture de la Truffe; 1999; Aix-en-Provence, France; Federation Française des trufficulteurs; 1999; 257-9.

[38] Lulli L, Bragato G, Gardin L. Occurrence of Tuber melanosporum in relation to soil surface layer properties and soil differentiation. Plant Soil 1999; 214: 85-92.

[39] Sourzat P. Les limites des criteries agronomiques dans l'analyse de terre en truffle culture. In: Corvoisier M., Olivier JM. and Chevalier G, Eds. Actes du V Congrès International Science et Culture de la Truffe; 1999: Aix-en-Provence, France: Federation Française des trufficulteurs $2001 ; 281-8$.

[40] Castrignano A, Goovaerts P, Lulli L, Bragato G. A geostatistical approach to estimate probability of occurrence of Tuber melanosporum in relation to some soil properties. Geoderma 2000; 98: 95113.

[41] García-Montero LG. Estudio sobre la trufa negra Tuber melanosporum Vitt. en el centro de España: patrones ecológicos, análisis edáficos e interacciones de micorrizas en la truficultura. Universidad de Alcalá, Ph Degree, Alcalá de Henares; 2000.
[42] Granetti B, De Angelis A, Materozzi G, Eds. Umbria terra di tartufi. Terni: Regione Umbria; 2005.

[43] García-Montero LG, Casermeiro MA, Hernando J, Hernando I. Soil factors that influence the fruiting of Tuber melanosporum (black truffle). Aus J Soil Res 2006; 44: 1-8.

[44] García-Montero LG, Casermeiro MA, Hernando I, Hernando J. Effect of active carbonate, exchangeable calcium, and stoniness of soil on Tuber melanosporum carpophore production. N Z J Crop Hortic Sci 2007; 35: 139-46.

[45] García-Montero LG, Casermeiro MA, Manjón JL, Hernando I. Impact of active soil carbonate and burn size on the capacity of the rockrose Cistus laurifolius to produce Tuber melanosporum carpophores in truffle culture. Mycol Res 2007; 111: 734-9.

[46] García-Montero LG, Manjón JL, Martín-Fernández S, Di Massimo G. Problems of using pines in Tuber melanosporum culture: soils and truffle harvest associated with Pinus nigra and P. sylvestris. Agrofor Sys 2007; 70: 243-9.

[47] García-Montero LG, Díaz P, Martín-Fernández S, Casermeiro MA. Soil factors that favour the production of Tuber melanosporum carpophores over other truffle species: a multivariate statistical approach. Acta Agriculturae Scandinavica Section B-Soil and Plant Science 2008; in press.

[48] Poitou N. Cas particulier des sols truffieres. Bulletin FNPT-CTIFL 1988; 10: 11-6.

[49] Coli R, Maurizi A, Granetti B, Damiani P. Composizione chimica e valore nutritivo del tartufo nero Tuber melanosporum Vitt. e del tartufo bianco Tuber magnatum Pico raccolti in Umbria. In: Bencivenga M, Granetti B, Eds. Atti del Secondo congresso internazionale sul tartufo; 1988: Spoleto, Italy: Comunità Montana dei Monti Martani e del Serano; 1990; 511-6.

[50] López J, López J. El diagnóstico de suelos y plantas. Madrid: Mundi-Prensa; 1990.

[51] Wild A. Condiciones del suelo y desarrollo de las plantas según Russel. Madrid: Mundi-prensa; 1992.

[52] Breemen NV, Buurman P. Soil formation. Dordrecht: Kluwer Academic Publishers; 1998.

[53] Marañés A, Sánchez JA, Haro S, Sánchez ST, Lozano FJ, Eds. Análisis de Suelos, metodología e Interpretación. Almería: Universidad de Almería; 1994.

[54] Ourzik A. Les sols argilocalcaires à potentiel truffier de la Vienne. In: Corvoisier D, Olivier JM, Chevalier G, Eds. Actes du V Congrès International Science et Culture de la Truffe; 1999: Aixen-Provence, France; Federation Française des trufficulteurs 2001; 273-4.

[55] Montacchini F, Fasolo-Bonfante P, Fontana A. Inibitori naturali della germinazione. Un esempio: Tuber melanosporum Vittad. Informatore Botanico Italiano 1972; 4: 156-9.

[56] Papa G. Componenti di Tuber melanosporum con attività fitotossica. Micologia e Vegetazione Mediterranea 1992; 7: 109-10.

[57] Plattner I, Hall IR. Parasitism of non-host plants by the mycorrhizal fungus Tuber melanosporum. Mycol Res 1995; 99: 1367-70.

[58] García-Montero LG, Di Massimo G, García-Abril A, Grande MA Suitability of lime trees for Tuber melanosporum culture: soil studies and truffle harvest associated with Tilia platyphyllos and T. $x$ vulgaris. Sydowia 2007; 59: 46-56.

[59] García-Montero LG, Pascual C, García-Abril A, García-Cañete J. Problems of using rockroses in Tuber melanosporum culture: soil and truffle harvest associated with Cistus laurifolius. Agrofor Sys 2007; 70: 251-8.

[60] Environmental-Department. Spanish Forestry Strategy. Madrid: Environmental Department of Spain; 1999.

[61] Environmental-Department. Spanish Forestry Plan. Madrid: Environmental Department of Spain; 2002.

[62] Reyna S, De Miguel AM, Hernández A. Situación y perspectivas de la truficultura en España. In: Sociedad Española de Ciencias Forestales, Ed. III Congreso Forestal Español. Sociedad Española de Ciencias Forestales, Granada, Spain; 2001; 723-30.

[63] García-Montero LG, Moreno A, Pascual C, Manjón JL. Evaluación del clima en la producción trufera (trufa negra: Tuber melanosporum Vitt.) del Alto Tajo (Guadalajara y Cuenca). Revista Forestal Española 2002; 31: 23-9.

[64] TESEO database. Available from: http://teseo.mec.es/teseo/jsp/ teseo.jsp.

[65] Díaz P. Optimización del aroma de trufa Tuber aestivum mediante microextracción en fase sólida del espacio de cabeza (HS-SPME). 
Unpublished first phase of thesis, University Autónoma of Madrid, Madrid; 2002.

[66] Reyna S. Aproximación a una selvicultura trufera. Ph Degree, Technical University of Madrid, Madrid; 1999.

[67] Domínguez JA. Aportaciones de la micorrización artificial con trufa negra en planta forestal. Ph Degree, Technical University of Madrid, Madrid; 2002.

[68] Domínguez JA, Selva J, Rodríguez JA, Saiz de Omeñaca JA. The influence of mycorrhization with Tuber melanosporum in the afforestation of a Mediterranean site with Quercus ilex and Quercus faginea. For Ecol Manag 2006; 231: 226-33.

[69] García-Montero LG, Di Massimo G, Manjón JL, García-Cañete J. The effect of Sphaerosporella brunnea mycorrhizas on mycorrhization of Quercus ilex x Tuber melanosporum. Submitted 2008.

[70] García-Montero LG, Di Massimo G, Manjón JL, García-Abril A. International research on the taxonomy, ecology, soils and mycorrhizae of Chinese Tuber, and their impact on truffle culture. Submitted 2008

[71] García-Montero LG, Di Massimo G, Manjón JL, Velázquez J. Description of Tuber malençonii mycorrhizae and a comparison with mycorrhizae of T. aestivum and T. mesentericum. Submitted 2008.

[72] García-Montero LG, Di Massimo G, Manjón JL, García-Abril A. New data on ectomycorrhizae, taxonomy and soil tolerance of the chinese truffles Tuber pseudoexcavatum and T. indicum. Submitted 2008.

[73] Amicucci A, Rossi I, Potenza L, et al. Identification of ectomycorrhizae from Tuber species by RFLP analysis of its region. Biotechnol Lett 1996; 18: 821-6.

[74] Zambonelli A, Tibiletti E, Pisi A. Caratterizzazione anatomomorfologica delle micorrize di Tuber indicum Cooke and Massee su Pinus pinea L. e Quercus cerris L. Micologia Italiana 1997; 1: 29-36.

[75] Comandini O, Pacioni G. Mycorrhizae of Asian black truffles, Tuber himalayense and T. indicum. Mycotaxon 1997; 63: 77-86.

[76] Etayo ML. Seguimiento del estado de micorrización de una parcela de cultivo de trufa negra. Valoración del simbionte arbóreo y efecto del tratamiento de alcochado. Estudio preliminar de las micorrizas de un área trufera colindante. Ph Degree, University of Navarra, Pamplona; 2001.

[77] Román M. Las ectomicorrizas de Quercus ilex subsp. ballota y su dinámica post-incendio en una zona potencialmente trufera. Ph Degree, University of Navarra, Pamplona; 2002

[78] Martínez de Aragón J. Producción de esporocarpos de hongos ectomicorrícicos y valoración socioeconómica. Respuesta de estas comunidades a incendios forestales. Ph Degree. University of Lleida; 2005.

[79] Wang Y, Moreno G, Riousset LJ, et al. Tuber pseudoexcavatum sp. nov. A new species from China commercialised in Spain, France and Italy with additional comments on Chinese truffles. Cryptogamie Mycologie 1998; 19: 113-20.

[80] Moreno-Arroyo B, Infante F, Pulido E, Gomez J. The biogeography and taxonomy of Tuber oligospermum (Tul. and C. Tul.) Trappe (Ascomycota). Cryptogamie Mycologie 2000; 21: 147-52.
[81] Díaz P, Ibáñez E, Señoráns FJ, Reglero G. Truffle aroma characterization by headspace solid-phase microextraction. J Chromatogr A 2003; A 1017: 207-14.

[82] Díaz P, Señoráns FJ, Reglero G, Ibáñez E. Truffle aroma analysis by headspace solid phase microextraction. J Agric Food Chem 2002; 50: 6468-72.

[83] Suz LM, Martin MP, Colinas C. Detection of Tuber melanosporum DNA in soil. FEMS Microbiol Lett 2006; 254: 251-7.

[84] Bellesia A, Pinetti A, Tirillini B, Bianchi A. Temperaturedependent evolution of volatile organic compounds in Tuber borchii from Italy. Flavour Fragance J 2001; 16: 1-6.

[85] Piloni M, Tat L, Tonizzo A, Battistutta F. Aroma characterisation of white truffle by GC-MS and GC-O. Ital J Food Sci 2005; 17 : 463-8.

[86] Saltron F, Fayet B, Guerere M. Contribution to the characterization of truffle juices from Tuber melanosporum, T. brumale, T. aestivum and T. indicum. Sci Aliments 1997; 17: 497-505.

[87] Talou T, Delmas M, Gaset A. The volatile components of tinned Black Perigord Truffles Tuber melanosporum Vittad. Flavour Fragance J 1989; 4: 109-12.

[88] Bianco L, Marucchi M, Cossa P. Aromi naturali ed artificiali nei tartufi e negli alimenti. Industrie Alimentari 1988; 27: 518-24.

[89] Pacioni G, Bellina-Agostinone C, D'Antonio M. Odour composition of the Tuber melanosporum complex. Mycol Res 1990; 94: 201-04.

[90] Talou T, Delmas M, Gaset A. Principal Constituents of Black Truffle (Tuber melanosporum) Aroma. J Agric Food Chem 1987; 35: 774-7.

[91] Zeppa G, Gerbi V. Using an "electronic nose" to discriminate white truffle (Tuber magnatum Pico) quality. Sciences des Aliments 2001; 21: 683-95.

[92] Persaud C, Gaset A, Talou T. Procédé et dispositif pour la localisation des truffes par la détection des composés volatils émis par ces dernières. France; 1994.

[93] Díaz P, García-Montero LG, Ibánez E, Señoráns FJ, PérezAndueza G. Caracterización de compuestos atrayentes de insectos en trufas españolas mediante microextracción en fase sólida. In: Díaz P, Díaz-Moral D, Lucini C, Pérez-Andueza G, Santamaría T, Eds. III Congreso Nacional de Entomología Aplicada. 2003: Ávila, Spain: Catholic University de Ávila; 2003.

[94] Pacioni G, Bologna MA, Laurenzi M. Insect atraction by Tuber: a chemical explanation. Mycol Res 1991; 95: 1359-63.

[95] Talou T, Gaset A, Delmas M, Kulifaj JM Montant C. Dimethyl sulphide: the secret for black truffle hunting by animals. Mycol Res 1990; 94: 277-8

[96] Ciampolini M, Suss L. New findings on garlic fly, Suillia univittata (von Roser) (Diptera Heleomyzidae). Bollettino di Zoologia Agraria e di Bachicoltura 1984; 17: 19-38.

[97] Bonet JA, Fischer CR, Colinas C. Cultivation of black truffle to promote reforestation and land-use stability. Agron Sustain Dev 2006; 26: 69-76.

[98] Reyna S, Ed. Truficultura. Fundamentos y técnicas. Madrid. Mundi-Prensa; 2007.

(C) García-Montero et al.; Licensee Bentham Open.

This is an open access article distributed under the terms of the Creative Commons Attribution License (http://creativecommons.org/licenses/by/2.5/), which permits unrestrictive use, distribution, and reproduction in any medium, provided the original work is properly cited. 